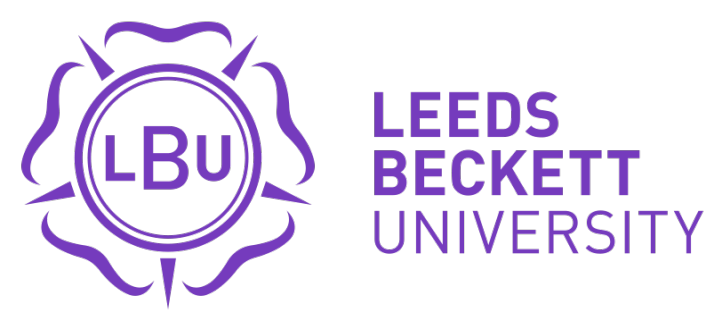

Citation:

Zobel Marshall, E (2021) Carnival, Calypso and Dancehall Cultures: Making the Popular Political in Contemporary Caribbean Writing. In: Caribbean Literature in Transition, 1970-2015. Cambridge University Press, pp. 52-68. ISBN 9781108474009

Link to Leeds Beckett Repository record:

https://eprints.leedsbeckett.ac.uk/id/eprint/7322/

Document Version:

Book Section (Published Version)

This material has been published in Caribbean Literature in Transition, 1970-2015 edited by Ronald Cummings and Alison Donnell. This version is free to view and download for private research and study only. Not for re-distribution or re-use. (C) Cambridge University Press 2020

The aim of the Leeds Beckett Repository is to provide open access to our research, as required by funder policies and permitted by publishers and copyright law.

The Leeds Beckett repository holds a wide range of publications, each of which has been checked for copyright and the relevant embargo period has been applied by the Research Services team.

We operate on a standard take-down policy. If you are the author or publisher of an output and you would like it removed from the repository, please contact us and we will investigate on a case-by-case basis.

Each thesis in the repository has been cleared where necessary by the author for third party copyright. If you would like a thesis to be removed from the repository or believe there is an issue with copyright, please contact us on openaccess@leedsbeckett.ac.uk and we will investigate on a case-by-case basis. 


\title{
Carnival, Calypso and Dancehall Cultures: Making the Popular Political in Contemporary Caribbean Writing
}

\author{
Emily Zobel Marshall
}

The intermixing of literary, oral and performance cultures has long been the bedrock of Caribbean writing. Through an analysis of contemporary writing by Anthony Joseph, Nalo Hopkinson, Monique Roffey, Marcia Douglas, Robert Antoni, Nicolás Guillén and Tanya Shirley, this essay demonstrates how contemporary Caribbean writing embraces popular culture to challenge Euro- and American-centric ideologies and destabilize the perceived boundaries between oral and scribal cultures. Popular culture in these texts challenges the writer to experiment with form, language and rhythm rooted in call-and-response, folklore traditions, and Caribbean musical forms such as reggae, calypso, dancehall, mento, zouk, bélé and Afro-Cuban drumming. Drawing from conceptualizations of Caribbean culture in the work of critics Gerard Aching (2002), Antonio Benítez-Rojo (1992), Kevin Adonis Browne (2018), Carolyn Cooper (1993, 2004) and Kwame Dawes (I999), this essay demonstrates how the oral is always whispering below the surface of the written text as Caribbean authors permeate their writings with soundscapes of Caribbean languages and music. ${ }^{\text {I }}$ Importantly too, drawing from the rich cultural traditions of the region also becomes a means through which the poetic and literary become explicitly political. These writers fulfil Kamau Brathwaite's celebrated call in 'Jazz and the West Indian Novel' (1967) for the Caribbean artist to draw from and acclaim their indigenous, local cultural forms and community; ${ }^{2}$ yet they also adapt and adopt popular culture with a critical eye, particularly in relation to the misogyny and sexism often performed within dancehall and carnival cultures.

\section{Serious Mas: The Caribbean Novel and Carnival Cultures}

Carnival forms the bedrock of numerous Caribbean novels, amongst them Wilson Harris's Carnival (1985), Lawrence Scott's Witchbroom (1992) and Willi Chen's short story collection King of Carnival and Other Stories 
(I988). However, no Caribbean author has done more to foreground the centrality of carnival and masquerade (mas) in the Caribbean than Trinidadian writer Earl Lovelace. Although best known for his novels, his collection of plays Jestina's Calypso and Other Plays also demonstrates, as Errol Hill convincingly outlines in his study The Trinidad Carnival: Mandate for a National Theatre (1972), that carnival can provide a key directive and site for Caribbean theatre practice. ${ }^{3}$

In Trinidad, traditional mas continues to provide a creative medium for scrutinizing an oppressive and traumatic past as well as highlighting flaws in contemporary society. Masquerades keep creative traditions of carnival alive, and, at a deeply personal and psychological level, playing mas is also transformative. Kevin Adonis Browne outlines a form of 'carnival poetics' in High Mas: Carnival and the Poetics of Caribbean Culture (2018). ${ }^{4}$ Browne argues, in his self-reflexive and inventive text, which straddles academic, poetic, polemic and visual registers and directly addresses the reader (insisting on their active participation), that carnival poetics is the recognition that you don't just 'play' mas - you live it.

Mas, Browne insists, like Lovelace's protagonist Aldrick Prospect in The Dragon Can't Dance (1979), is never only symbolic. Each performer brings themselves to the role and decides how they want to be viewed; there is a deeply individual motive at work in each mas performance (30). Like the generation of influential Caribbean writers that preceded him, including Derek Walcott, Kamau Brathwaite, Errol Hill and Wilson Harris, Browne sees Caribbean culture as fragmented. The gathering of these fragments is a creative Caribbean process epitomized by carnival. The past, he concludes, is not reclaimable, but we (the people of the Caribbean and its diaspora) must embrace fragmentation. Carnival allows us to piece ourselves back together, like sticking feathers on a carnival costume, while celebrating the cracks and seams still on show (I4-I 5, I7). Cracking and repair are part of the history of the Caribbean and should not be disguised. As Walcott asserts, 'Antillean art is this restoration of our shattered histories, our shards of vocabulary, our archipelago becoming a synonym for pieces broken off from the original continent.'

Cuban poet and author Antonio Benítez-Rojo also uses carnival as a central discourse of Caribbean cultural dynamics in the closing chapter of The Repeating Island: The Caribbean and the Postmodern Perspective (1989). Here he conceptualizes 'Caribbeanness' through carnival as a complex sociocultural interplay: 'A system full of noise and opacity, a nonlinear system, an unpredictable system, in short a chaotic system beyond the total reach of any specific kind of knowledge or interpretation of the world. ${ }^{6}$ 
Benítez-Rojo argues that the analysis of Caribbean culture has been too strongly focused on either African cultural retentions or 'New World' cultural clashes. Critics have missed something fundamental about the complexity of the varied, multifaceted nature and 'chaotic coexistence' (303) of Caribbean culture and identity, a 'cultural sea without frontiers' (295) whose flows criss-cross and connect the cultures of Africa to the diaspora and beyond.

Benítez-Rojo turns to the strong Hispanic cultural influences in the Caribbean and closely examines a poem by Cuban poet Nicolás Guillén entitled 'Sensemaya: Canto para matar una culebra' (Sensemaya: chant for killing a snake), which he demonstrates is steeped in Afro-Cuban rhythms and ideology. The rhythmic structure and themes of the poem draw from African religious traditions and snake killing rituals performed during slave pantomimes and in post-emancipation Cuban carnivals (302). BenítezRojo concludes that the sounds of the poem allow the listener/reader into the secrets of its cultural history: "The sounds "Mayombebombemayombé", "Sángala culembe”, "Sángala muleque”, "Sanga lamulé", and "Calabasón-són-són", oscillate between Africa and Cuba and give a sacrificial meaning to anthropological terms such as "Afro-Cuban" and "transculturation" (298). Like Browne, Benítez-Rojo sees carnival as an expression of the attempt to unify that which ultimately cannot be unified and as the most representative cultural expression of the multiplicity of Caribbeanness: 'Of all possible sociocultural practices, the carnival - or any other equivalent festival - is the one that best expresses the strategies that the people of the Caribbean have for speaking at once of themselves and their relation with the world, with history, with tradition, with nature, with God' (294).

Earl Lovelace's The Dragon Can't Dance (I979) also articulates this keen appreciation for the self-defining power of carnival and the emancipatory and spiritual force of mas through the story of Aldrick Prospect, who lives for nothing else but to work on his exquisite Dragon costume and play Dragon mas. Aldrick's dragon dance through the streets shows how Trinidad carnival becomes a vehicle through which the poor and dispossessed inhabitants of Calvary Hill can assert their strength and humanity: 'He danced to say, "You are beautiful, Calvary Hill and John John and Laventille and Shanty Town. Listen to your steelbands how they playing! Look at the colours of your costumes in the sunshine! [...] You is people."”7

Poverty pervades Lovelace's stories, and central to the motivations of his protagonists is the desire to be seen, to be recognized and to be made visible 
in a world in which they are overlooked as a result of racial and socioeconomic status. The myth of carnival as a hedonistic ritual fuelled by rum and bikini-clad bodies is challenged by the seriousness of mas in Lovelace's writings. Aldrick doesn't just play but becomes the Dragon: all-powerful, beautiful, fierce, and mesmerizing in the carnival moment. Indeed, we might read this not only in Benítez-Rojo's cultural terms of 'transculturation' but in relation to the performative power of transformation.

Gerard Aching argues in Masking and Power: Carnival and Popular Culture in the Caribbean (2002) that Lovelace's financially (but not culturally) impoverished community on the 'Hill' embraces an ideology of non-possession. The Hill's inhabitants cultivate a culture of antimaterialism as they hold onto 'their poverty as a possession'. ${ }^{8}$ While the acquisition of expensive possessions breeds the wrong sort of visibility and is considered a threat to the community, Aldrick's beautiful dragon mask releases him from the pain of social invisibility without the need for money. Through his skills in costume construction and masquerade, he grows in power and prestige; on the road he transcends his earthly form and joins the family of formidable carnival beasts and devils. Milla Riggio and Rawle Gibbons argue in their chapter 'Pay the Devil, Jab Jab: Festive Devils in Trinidad Carnival' in Festive Devils of the Americas (2015) that negative colonial associations between blackness and beastliness were destabilized and inverted by black Caribbeans playing the devil and beast characters at carnival: Co-opted by those whom it stigmatized [...] the mythic notion of blackness became a potent source both of power and festive danger, embodied in the often-forbidden practices of music, drumming and collective festivity - and in the emergence of a variety of devil characters.' It is little wonder therefore that Black Power forms part of the backdrop for Lovelace's narrative. Devil, dragon and beast carnival masquerades draw directly from histories of enslavement, symbolized by the beast in chains who lunges at the crowd and must be restrained by his keeper, and a variety of devil characters including Jab Molassie. ${ }^{\text {Io }}$

The climax of Trinidadian Monique Roffey's novel Archipelago (2012) also pivots on a carnival scene. The plot centres on a father named Gavin who must protect his quick-witted daughter, Ocean, and help her recover from the trauma of losing her baby brother in a house flood in Port of Spain. Ocean's mother is devastated by the death and is unable to communicate, so Gavin takes his daughter (and their beloved dog) on an epic and often dangerous sailing adventure around the Caribbean archipelago and, eventually, through the Panama Canal. The novel's moment of resolution is a carnivalesque outpouring that serves as a hopeful climax 
and heralds Gavin's metaphorical rebirth and transition out of trauma. Gavin finds peace in the carnival moment of jouvay, at daybreak, on the streets. He is also, in this moment, a white man painted black, which suggests a transformation (for Gavin) of his racial and historical positioning in Trinidad and perhaps signals a deeper sense of belonging:

This is Jouvay, jour overt, the opening of the day, of carnival, two days of celebration - and he is black, slick with mud and paint and wearing a cowboy hat with winking lights. There is his punch of rum slung around his neck. He is Bacchus, he is Dionysus, he is a drunken sailor man, a wild man, a lover man, he is home, back, a person from this particular island, lush and green and fertile, Trinidad, the end link in the chain of this long and dazzling archipelago. ${ }^{\text {II }}$

Trinidadian Robert Antoni's white protagonist in Carnival (2006) also loses his way in life but finds himself through immersion in the carnival moment. Here too carnival is a route to transition from earthy worries and concerns. The protagonist, a privileged young boy named William, struggles with sexual intimacy and returns to Trinidad for carnival. He remembers 'a solid mass of humanity, indistinguishable, embracing each other. Covered, head to toe, in every imaginable nastiness: axle grease, baby oil, flour, Quaker Oats, tar, mustard, peanut butter, Hershey's chocolate syrup in addition to the paint, mud'. ${ }^{2}$ For William this signals the ultimate moment of liberation: 'This - I told myself, I proclaimed it every year, every jouvert morning - this could save the world. / Standing in the middle of the mainstage, my head thrown back, staring up at the blinding sun' (I 56). The protagonist is 'swallowed up' by the crowds 'like a hot seawave of energy - of soca, naked limbs, whistles, smoke, diesel fumes, sweat' (I 53). In this moment he is overwhelmed by the feeling of belonging to the Trinidadian 'mas'. The connection felt by these white Trinidadians to the island and its people is complicated by centuries of colonialism and enslavement and while they are enraptured by their sense of being at one with the 'mas', as Roffey highlights in The White Woman on the Green Bicycle (2009), the 'mas' may not be as keen to overlook profound and persistent racial and economic divides.

In The White Woman on the Green Bicycle, Roffey's protagonist Sabine, a naïve, wealthy white woman living in Trinidad, around the time of independence, becomes obsessed with soon-to-be prime minster, Eric Williams. She sneaks out to hear one of his famous, rousing political speeches in the centre of Port of Spain and finds herself engulfed by carnival street crowds. The carnival moment here is not euphoric but rather forces the protagonist to confront the reality of her presence as a 
white colonial in a decolonizing Trinidad. Sabine hides behind her fan, a family heirloom, watching the spectacle with trepidation of an 'ol' mas band' arriving on a donkey cart with men with faces blackened with coal. A Midnight Robber makes his way through the streets and carnival bands scatter as he walks towards her; his whistle has an 'ear splitting screech': ${ }^{\mathrm{I3}}$ 'Eh, whitey. You here by yourself? Eh, eh, she pretty like pretty self, the robber taunts (254). He asks her how she likes it in Trinidad and a crowd gathers to watch him as he prepares to make a speech: 'Well, Miss, lemme tell yuh somptin: yuh days numbered. / Go back to where you came from. De Doc go put allyuh on a boat. / Send you home pack up head to foot, pack you tight, in chains' (254). Whites, the Robber says, will have a 'taste of their own treat-ment': 'Maybe we go bury you up to your neck near redant nest! Paste your pretty mout wid honey? (255). The crowd jeer and erupt as he describes the plantation punishments he could mete out on her; then 'The Robber Man lower[s] his head; we [are] eye to eye. "Or wossssss. Fill dat lovely ass of yours wid gunpowder"' (255). The Robber Man, through his mas, is able to speak the truth to power, but his gendered speech also makes Sabine acutely aware of her vulnerability as a white woman alone on the streets during carnival time. This carnival confrontation enables Sabine to develop an understanding of her precarious historical position as a rich white colonial living in a newly independent country.

Jamaican author Nalo Hopkinson's science fiction novel The Midnight Robber (2000) draws from the Midnight Robber's revolutionary energy and linguistic prowess to create an alternative vision of the Caribbean future that steers the Midnight Robber away from his traditional role as emblem of masculine potency. Hopkinson's protagonist Tan-Tan lives on a futuristic Caribbean planet named 'Toussaint' (after Toussaint Louverture) controlled by an all-seeing, omnipotent 'Granny Nanny', named after the historical figure, Nanny of the Maroons. Tan-Tan is kidnapped by her abusive father to another dimension, New Half Way Tree, during carnival, wearing her beloved Midnight Robber costume. Here Hopkinson uses Half Way Tree, a Kingston location, to depict a liminal portal to other worlds, a motif also employed in Marcia Douglas's The Marvellous Equations of the Dread: A Novel in Bass Riddim (2018).

In New Half Way Tree, Tan-Tan must learn to become the trickster rather than the dupe in order to survive. Following the brutal trauma of being raped by her father and falling pregnant, she metamorphoses into both an Anansi figure and the 'Robber Queen'. Hopkinson recasts the traditional male Midnight Robber placing a young black pregnant woman 
at the centre of the mas. Tan-Tan's greatest weapon, her robber-talk, centres around stories of the injustices she has suffered, and through storytelling she is freed: 'Her voice swelled with power as the Robber Queen persona came upon her' ${ }^{\text {'4 }}$ and 'power coursed through Tan-Tan, the Robber Queen's power - the power of words' (319). Through her Robber Queen speeches, Tan-Tan cements ancestral bonds to the powerful African, Taíno and Caribbean women who came before her, transcending her human form to become her mas character:

"Not wo-man; I name Tan-Tan, a "T" and an "AN"; I is the AN-acaona, Taíno redeemer; the AN-nie Christmas, keel boat steamer; the Yaa As-ANtewa; Ashanti warrior queen; the NAN-ny, Maroon Granny; meaning Nanna, mother, caretaker to a nation. You won't confound these people with your massive fib-ulation!' And Tan-Tan the Midnight Robber stood tall, guns crossed at her chest. Let her opponent match that. (320)

Hopkinson, Roffey, and Antoni draw from carnival and the Midnight Robber figure to signal moments of epiphany and awakenings in their texts. Carnival also functions as a medium though which the protagonists are confronted by or attempt to transcend their gendered and racial positioning in relation to the island's history and culture. Carnival here is rapture and enlightenment but also often signals the impossibility of true escape from the fractured and racialized histories of the Caribbean.

\section{Calypso Poetics}

Like carnival, the presence of popular music and song in Caribbean writings offers a means through which scribal, oral and performance cultures can be fused to create new literary forms that express the multifaceted, mercurial and ever-changing shape of Caribbean culture. Calypso, reggae, dub and dancehall aesthetics have shaped the literary output of Caribbean writers and been important in the theoretical work of key Caribbean literary and cultural scholars.

Kitch (2018) by Trinidadian-born author Anthony Joseph traces the life of Trinidadian calypso singer Lord Kitchener, who was famously filmed singing 'London is the Place for $\mathrm{Me}$ ' from the deck of the Empire Windrush in I948. Joseph combines the factual and fictional to carefully plot 'Kitch's' evolution from a country-boy (nicknamed 'Bean') to a global star. Kitch is both thematically and stylistically intermingled with Caribbean calypso cultures; drawing from the calypso aesthetics of Earl Lovelace and Samuel Selvon, Joseph is part of a new generation of 
Caribbean writers whose work is infused with calypso rhythms and lyricism. Joseph makes frequent use of double-entendre, which he calls 'a calypso motif and draws from the humour and politics of calypso. ${ }^{15}$ According to Joseph, 'what inspired me to write was listening to people like the Mighty Sparrow who would use language is such a profound way' ${ }^{\text {I6 }}$

Several of Joseph's chapters begin with lyrics or refrains from Kitch's calypsos. The well-known calypso refrain Sans Humanité frames the chapter 'Coronation Calypso', fragmenting the main body of the text and creating a repetitive, call-and-response rhythm and a tempo alongside the vivid descriptions of the mighty calypsonians gathering in the calypso tent. This refrain is one of the most popular extempo (improvised) calypso refrains that requires an audience response. Sans Humanité translates from French as 'no mercy', or 'without humanity', a reflection of the brutality of Trinidadian history and contemporary poverty, which also asserts the lack of mercy the calypsonian has for his opponent.

While Joseph highlights the consciously political nature of Kitch's calypsos, which draw attention to social injustice and the abuse of power, he also examines the gendered nature of power in the life of Kitch. A very short chapter is dedicated to a first-person narrative from the perspective of Marjorie, Kitch's long-suffering white British wife, and her friend Martha as they narrate their early sexual adventures with black men and introduction onto the Caribbean calypso scene in Manchester. While he had a string of affairs, Kitch was notoriously jealous, and his suspicion over his wife's involvement with black American soldiers forms the basis of his calypso entitled 'Marjorie's Flirtation', which Joseph incorporates into the novel:
Marjorie I am tired of you
For you are not really true.
For every time I walk the stand
I can hear you were loving up some Yankee man
I can hear you were loving up some Yankee man.
Ah going to bet you - he was a big Yankee man
Ah going to beat you - he was a rough Yankee man. ${ }^{17}$

In the chapter narrated by Sonny Greene in I953, Joseph reflects dominant attitudes towards women during the period of Kitch's rise to fame. In this way we might mark connections between Joseph's text and Sam Selvon's earlier works that narrate the sexual adventures of Caribbean migrants in 1950 L London. Describing Kitch as a hustler and a pimp, Greene excuses his role by pointing out that many Caribbean men were 
'poncing' (prostituting) white women. However, given that women were deeply involved in Kitch's scene and were a part of his everyday entourage, by returning to a male narrative perspective, Joseph misses an opportunity to properly counterbalance and undercut the misogynistic male voice through the incorporation of reimagined women's narratives in his novel.

If the use of the voice of the calypsonian proves important to Joseph's writing, along with the earlier work of Selvon and Lovelace, we can also note how the calypsonian's voice has also been important for theorizing the Caribbean. In a discussion with Kamau Brathwaite, the critic Gordon Rohlehr has argued that 'calypso provides us with living examples of a very complex metric organization of language. It is not simply a matter of using WI speech rhythms and idioms, but of being conscious of the syncopated drum-rhythms in the background'. ${ }^{8}$ Both Rohlehr and Brathwaite have explored the power and poetry of the Mighty Sparrow's songs as well as talked about the use of rhythm and language of calypso as a resource for the Caribbean poet. Their work has been complemented by Maureen Warner-Lewis's keen examination of calypso aesthetics in the novels of Selvon and Lovelace. ${ }^{19}$ However, in Rohlehr's work, we might additionally note that calypso functions both as subject and style in his politics of response, use of picong ${ }^{20}$ and his engagement with the voice and figure of the 'bookman' in Perfected Fables Now: A Bookman Signs Off on Seven Decades (2019).

\section{Reggae and Dub Aesthetics}

The politics of reggae and dancehall culture has also been theorized by a number of key Caribbean literary critics, amongst them Kwame Dawes and Carolyn Cooper. Both have simultaneously argued that we must take seriously the poetics of the popular while also mapping ways in which Caribbean literary production has been in conversation with, and drawn on, popular aesthetics and cultural forms. Carolyn Cooper has, for instance, examined what she has termed 'Bob Marley's literary legacy '2 through close readings of the poetics of his songs while also pointing to a wider body of 'Lit/orature' and examining the multiple sound resources and verbal creativity employed in a number of folk, popular, performance and written texts. ${ }^{22}$

Kwame Dawes's book Natural Mysticism: Towards a New Reggae Aesthetic (1999) begins with an exploration of the influence of Bob Marley's music on Jamaican literature. Pointing to the poetry and influence of Marley's verse, Dawes examines connections, for instance, between 
Marley's music and Colin Channer's novels, which take titles from Marley's songs (Waiting in Vain [1998], Satisfy My Soul [2002]). Dawes even titles his own 2007 novel, She's Gone, after a Marley song. While offering a theoretical argument, it is significant that Dawes resists the academic mode of critical definition in articulating his 'reggae aesthetic' and moves towards a lyrical, poetic mode of characterization by opening several of the book's chapters with poems (several of which are titled 'Some Tentative Definitions'). Marlon James's A Brief History of Seven Killings (20I4) might also be belatedly situated in relation to Dawes's attempt at a reggae aesthetic. In James's novel, the figure of the Singer, a character who has been discussed by critics as a representation of Marley himself, is central to the story as the novel recounts his attempted assassination.

Marcia Douglas's The Marvellous Equations of the Dread: A Novel in Bass Riddim (2018) firmly locates contemporary Caribbean writing in a musical milieu. Her work, a 'novel in bass riddim', is embedded in dub music and Rastafarian religious thought. Multiple spiritual domains exist side by side as Bob Marley and Haile Selassie converse on the 'dub side' and Marley returns, in the shape of a homeless fallen angel, on a spiritual quest to Half Way Tree in Kingston - a landmark also used by Hopkinson to suggest a liminal space and the crossroads of different dimensions. This non-linear novel embraces the music, mysticism and magic of Rastafari through a collage-like dub narrative, which zig-zags through time and space.

Critic Njelle W. Hamilton tracks the depiction of 'Caribbean spacetime' in Douglas's novel, demonstrating how her privileging of the reengineering technologies of dub music creates new spatial and temporal dimensions for her readers to explore. The famous clock tower in Kingston's Halfway Tree is a portal in Marvellous Equations, which never keeps the 'correct' time and connects the world of the living with the 'dub side'. Hamilton argues that the 'quantum temporality' of the echo and reverb effects in dub music, which underpin the narrative theme and form of the novel, create a soundscape text crafted around the sonic tremors of historical trauma. ${ }^{23}$ These are 'anti-clock' forms of storytelling, narrative movement and memory, which push the reader to work both forwards and backwards through the narrative, rocked by the (historical) vibrations of dub embedded in the text. ${ }^{24}$

Isis Semaj-Hall has argued that dub music, often based on well-known reggae tunes remastered and reworked, was a musical form born out of the hopes and frustrations of a newly independent Jamaica in the I960s. Like Hamilton's focus on 'historical trauma', Semaj-Hall insists that the dub bassline is a 'historical echo' that forces the listener to engage with a type of 
re-memory; like the sound of a mother's heartbeat experienced in the womb or the call of the African drum, dub takes the listener into an 'archive of memory'. ${ }^{25}$ While this memory archive forms the basis of both reggae and dub music, it is dub that 'opens up' and complicates the memory archive for critical examination. Outlining what she terms 'dub aesthetics', Semaj-Hall notes that B-side dub vinyl recordings were traditionally remastered versions of A-side reggae tunes: 'In more literary terms, one could say that the B-side dub is derivative, a reconstruction of the deconstructed A-side recording that adds to and emphasizes some production elements and mutes others.' According to Semaj-Hall, using the dub aesthetic in literature, as Douglas does, forces the reader and critic of the dub text to engage with key critical questions: 'What is being reverberated? What is being mixed? Whose voice is providing the talk-over? And whose voice is being muted or amplified?' Compelled to scrutinize the literary soundscape of reverberation and mixing, and to hear the narrative 'talkover', the reader engages with the archive of Caribbean historical memory. While also turning to a sound-archive, like previous reggae literary scholarship, the dub aesthetic is a new way of entwining memory and community with the business of literary criticism.

\section{Dancehall Erotics}

The focus on reggae poetics has not only influenced this dub aesthetic but has also been important in the critical engagement with dancehall erotics as a creative cultural force. Carolyn Cooper's Noises in the Blood: Orality, Gender, and the 'Vulgar' Body of Jamaican Popular Culture (I993) has been a key text in exploring issues of gender, 'slackness', and women's sexuality and agency within dancehall cultures, suggesting that a tension exists between the official scribal, 'literary' culture of Jamaica and the 'rude', 'slack' oral culture of dancehall which she reads as a form 'of verbal maroonage'. ${ }^{26}$ Cooper traces this tension in the work of Caribbean writers publishing from the I950s onwards: Louise Bennett, Vic Reid and, later, Erna Brodber. To this list, we can add the post-millennial authors Marcia Douglas and Tanya Shirley, who both command what Cooper describes as the full breadth of the 'scribal/oral literary continuum' (8I). In her close analysis of dancehall lyrics, Cooper demonstrates their intertextuality sitting at the intersection between oral and scribal culture and drawing from 'traditional' Caribbean cultural forms such as revival, folksongs, ring tunes and mento songs (I36-7). These often deeply subversive lyrics, deemed as vulgar and violent by officialdom, are firmly at odds with the 
'pious morality of fundamentalist Jamaican society' (I 4I). Lyrics not only express a rebellion against law and order but, similarly to the role of carnival in Lovelace's texts, are also a form of social commentary on ghetto violence, sexual violence and poverty (I43). According to Cooper, the Christian suppression of female sexuality is challenged in a dancehall culture that both celebrates and devalues female sexual agency through 'vulgarity' (136).

In Merchant of Feathers (2014), Jamaican poet Tanya Shirley tackles the misogyny of Caribbean popular culture head-on while locating dancehall as a space for female erotic expression. In 'How Dreams Grow Fat and Die', Shirley contrasts the rigidity of ballet classes to the 'looseness' and freedom of dancehall. Ballet is described in terms of practising walking, in agony, all summer on wooden-tip shoes. In the autumn, her dreams are thwarted when her ballet teacher tells her mother she is 'too fat to be a ballerina'. ${ }^{27}$ The teacher with her 'faux British accent and hollowed / collar bones [the girl] imagined were tea cups' (I 2 ) withers the little girl's dreams as her young black body will not adhere to the rules and contours of classical ballet:

You, who illustrated to my mother

My incompetence by drawing a circle

In the air. I was the round nightmare

Landing heavy in the melody of grand jetés.

(I 2)

Here ballet, with all its Eurocentricity, contrasts starkly with dancehall. In Shirley's poems, dancehall and reggae are mediums through which female sexuality is both celebrated and denigrated. While Cooper's celebration of dancehall lyrics as a radical means through which to challenge the restrictions of the church and state on female sexuality are echoed here, Shirley's poems also draw our attention to the devastating misogyny inherent in the dancehall DJ's lyrics and patter.

In 'Montego Bay', Shirley's protagonist describes dancing barefoot on the beach and wining to Bob Marley at an open-air sound system in an effort to gain the admiration of the man she loves. When a friend points out 'You don't wine to Bob', she retorts: 'But Bob would understand / What a woman has to do to hold a man / In this one room of sea and sky (33). The music becomes the vehicle for her seduction routine, and she rolls her hips, moves her breasts in 'slow/small circles, marking time with Marley' (33). She starts to speed up her 'gyration' to quench the thirst in his eyes, and the language becomes sensual and erotic. A reggae rhythm 
pushes through the text as she moves seductively to the beat: 'push back, roll and press forward', 'sideways rock and slither' this 'slow skank backwards / and forwards' (33). The object of her affections, however, remembers the 'obligations' to his wife, the need to pay school fees for his daughter, his 'ailing father / the overgrown lawn, church on Sunday' (33). The poem ends: 'You'll turn your back and I'll continue to dance' (33).

Here Shirley infuses her writing with the reggae beat of Marley's music and brings the woman centre stage in the act of seduction. The music and dancing here are sensual and alive - unlike the restricted ballet form and 'kukumkum orchestra' overseen by the sexless ballet teacher. In comparison to the faux British pomposity and failure to embrace life in all its diversity, epitomized by the ballet teacher, Marley's music provides a backdrop to a - thwarted - form of erotic expression. Perhaps you just can't properly 'wine to Bob', after all.

Elsewhere in her collection, Shirley is scathing of the misogynistic values that underpin elements of dancehall culture in Jamaica. In the poem 'SAID BY A DJ AT AN UPTOWN DANCE', the poem starts with the DJ's offensive utterance; 'Bruk off yuh head, mi buy it back a mawnin' (italics in original) and asks: 'And what is a woman's head, but dispensable / A dutty wining machine, a hypnotist's string. / A windmill' (43).

The poetic (and outraged) female voice is full of bitter sarcasm; she must, she concludes, have a man 'so rich' that he will go to the store and buy her a new head when she loses her own. While her new head undergoes a period 'of adjustment', she imagines her rich man will 'settle for deep discussions / with my breasts and marvel at the acquiescing nature / of my tender parts' (43). She continues: 'Matter of fact, which woman really needs a head / Unless she is proficient in giving head, / And keeping her mouth shut when she's not?' (43). Shirley suddenly brutally undercuts this mocking voice in her closing lines, which call attention to the actual violence regularly meted out on Jamaican women: 'Mr DJ, two headless women were found in Spanish Town; / Kindly give their families some money and directions to the store' (43).

In a sister poem, 'SAID BY A DJ AT A DOWNTOWN DANCE', Shirley compares the working-class downtown Kingston dance to an uptown middle-class dance and insists that the sexism and misogyny are equal in both locations. Again, Shirley pulls our attention towards the violence of the DJ's language and the casual sexism that can underpin dancehall culture: 'Big up yuhself if yuh pump um tight like mosquito coffin' 
(68; italics in original). By dissecting this seemingly throwaway comment she focuses the lens sharply on the absurdity and damaging impact of these words. She imagines her 'pum pum' coffin 'lined with purple velvet' (68) and proclaims: 'I want the men I have killed to rise up again, to sing halleluiahs in praise of this sweet spot' (68). The 'sweet spot' is smaller than 'a melon seed, a discarded tooth, a dew drop'; it is tighter than an 'eye socket', 'a screw, the space between seconds', than 'starched linen', 'a single mother's budget' or a 'stranglers hand on the throat' (68). The imagining of women as sexual objects is again undercut with the everyday realities of gendered violence and the challenges of motherhood and domesticity: 'Oh how we pray for resilience/ to bounce back in the face of dicks and pricks and big-headed babies':

And in the dance, surrounded by men, we flash up our lighters, point our fingers in gun salute, shout 'RAAEEE' in case we are mistaken for women whose pums pums could hold the coffin, the congregation, the choir, the hearse.

Here we find a rallying cry to women who try and align themselves to the image of the mosquito-tight 'pum pum', and a provocation to the men on the dancehall scene, to call out the normalization of sexism. Shirley lays bare the tensions between Jamaican dancehall cultures as sites of emancipation for women to wine freely and celebrate their bodies and spaces underpinned by chauvinism and controlled by the male gaze.

Conversely, the poem 'Night Nurse' is a love song to dancehall. Named after the famous song by lover's rock reggae star Gregory Isaacs, it describes a dancehall at three in the morning. A couple, tired of 'dodging [their] intentions', become enveloped in one another, 'forgetting' themselves and the routines and annoyances of mundane daily life: 'children, blemishes, spouses / bosses, leaky faucets' (67). As in 'Montego Bay', their coupling is illicit and signals an affair. They 'press against each other', and the rhythms of dancehall permeate as the text becomes, rather than responds to, the music:

I singe my backside

Into the swell of you groin

We are not moving to rhythm

We do not care for the deejay's gimmicks.

We are sound system enough -

Each circle of our waists, a low-lying bass.

An insistent pounding. 
Similar to the carnival climax in Roffey's, Hopkinson's and Antoni's works, in this moment the music has a profoundly transformative effect. The couple, unable to come together in 'Montego Bay', fall into a self-made rhythm. Refusing to be led to the 'gimmicks' of the DJ, dancehall here becomes conduit to self-expression - but only when translated into something meaningful by two individuals. Their yearning creates its own music and the dance; it is not born in the dancehall, yet the dancehall space allows them to set free their pentup desires and escape the banality of their lives in a temporary flash of passion and transcendence. Like the carnival revellers on Jouvay morning, they are liberated from the binds of social hierarchies and daily drudgery.

Contemporary Caribbean writers embrace the aesthetics of popular culture as a positive inheritance, yet their engagement with popular cultural forms has also been critical. They draw inspiration from calypso, dancehall, reggae and carnival cultures while challenging the patriarchal and heteronormative cultural politics embedded within them. Their literary works recentre questions of class, gender and power to examine the autonomy of women's voices and bodies and challenge misogyny, patriarchy and social injustice in the Caribbean and beyond.

\section{Notes}

I Gerard Aching, Masking and Power: Carnival and Popular Culture in the Caribbean (Minneapolis: University of Minnesota Press, 2002), Kevin Adonis Browne, High Mas: Carnival and the Poetics of Caribbean Culture (Jackson: University Press of Mississippi, 20 I 8), Carolyn Cooper, Noises in the Blood: Orality, Gender, and the 'Vulgar' Body of Jamaican Popular Culture, I 993 (Durham, NC: Duke University Press, 1995), Carolyn Cooper, Sound Clash (London and New York: Palgrave Macmillan, 2004), Kwame Dawes, Natural Mysticism: Towards a New Reggae Aesthetic (Leeds: Peepal Tree Press, I999).

2 Kamau Brathwaite, 'Jazz and the West Indian Novel', Bim, No. 44 (1967), 275-84; No. 45. (1967), 39-5 I; No. 46 (1968), I I 5-25.

3 Errol Hill, The Trinidad Carnival: Mandate for a National Theatre (Austin: University of Texas Press, 1972) and idem, Jestina's Calypso and Other Plays (London: Heinemann, 1984).

4 Browne, High Mas, 30. Subsequent references given parenthetically.

5 Derek Walcott, 'Nobel Lecture', nobelprize.org, 7 December 1992, www .nobelprize.org/prizes/literature/I992/walcott/lecture/. 
6 Antonio Benitez-Rojo, The Repeating Island: The Caribbean and the Postmodern Perspective, I989, trans. James E. Maraniss, 2nd ed. (Durham, NC: Duke University Press, 1996), 295. Subsequent references given parenthetically.

7 Earl Lovelace, The Dragon Can't Dance (London: Faber and Faber, I998), I I6.

8 Aching, Masking and Power, 53; Lovelace, The Dragon, Io.

9 Milla Riggio, Paolo Vignolo, Rachel Bowditch and Rawle Gibbons, eds., Festive Devils of the Americas (Kolkata: Seagull Books, 201 5), I90.

Io Jab is the French patois for Diable (Devil) and Molassie is the French patois for Mélasse (Molasses). In this devil mas the performer smears themselves with tar, grease, lard or engine oil. The 'molasses' is symbolic of burnt sugar cane and the Jab Molassie is said to represent the ghost of a slave burnt to death in the cane fields or in a fire in the cane factory, or a slave who has fallen to his death in a vat of molasses.

I I Monique Roffey, Archipelago (London: Simon and Schuster, 201 2), 357.

I 2 Robert Antoni, Carnival (New York: Black Cat, 2005), I 56. Subsequent references given parenthetically.

I 3 Monique Roffey, The White Woman on the Green Bicycle (New York: Simon and Schuster, 2009), 254. Subsequent references given parenthetically.

I4 Nalo Hopkinson, Midnight Robber (New York: Warner Books, 2000), 3 I7-I8. Subsequent references given parenthetically.

I 5 Hannah Silva, 'A Bit of Talk with Anthony Joseph', Interview with Hannah Silva, 30 April 20I8, http://hannahsilva.co.uk/a-bit-of-talk-with-anthonyjoseph/.

I6 Ibid.

I7 Anthony Joseph, Kitch (Leeds: Peepal Tree Press, 2018), I30. Italics in original.

I8 Edward Brathwaite, 'Gordon Rohlehr's "Sparrow and the Language of the Calypso", Caribbean Quarterly, I4.I (I968), 91-6, 92.

I9 Maureen Warner-Lewis, 'Samuel Selvon's Linguistic Extravaganza: Moses Ascending', Caribbean Quarterly, 28.4 (1982), 60-9.

20 Picong, or 'Piquant', is a Caribbean term for teasing, mocking or heckling others in a friendly verbal exchange - a type of Signifyin'; see Henry Louis Gates, The Signifying Monkey: A Theory of Afro-American Literary Criticism (New York: Oxford University Press, I988).

2I Carolyn Cooper, 'Bob Marley's Literary Legacy', The Sunday Gleaner, 8 February 2015 , http://jamaica-gleaner.com/gleaner/20 I 50208/cleisure/cleisure3.html.

22 Cooper, Sound Clash, 279.

23 Njelle W. Hamilton, 'Jamaican String Theory: Quantum Sounds and Postcolonial Spacetime in Marcia Douglas's The Marvellous Equations of the Dread, Journal of West Indian Literature, 27.I (2019), 89-101, 89.

24 Ibid. 
25 Isis Semaj-Hall, 'Re-membering our Caribbean through Dub Aesthetic', $s x$ salon, 2I (February 2016), http://smallaxe.net/sxsalon/discussions/re-member ing-our-caribbean-through-dub-aesthetic.

26 Cooper, Noises in the Blood, I 36. Subsequent references given parenthetically.

27 Tanya Shirley, The Merchant of Feathers (Leeds: Peepal Tree Press, 2014), I 2. Subsequent references given parenthetically. 